\title{
RNA-Binding Proteins Hold Key Roles in Function, Dysfunction, and Disease
}

\author{
Sophia Kelaini ${ }^{D}$, Celine Chan, Victoria A Cornelius and Andriana Margariti *
}

check for

updates

Citation: Kelaini, S.; Chan, C.;

Cornelius, V.A; Margariti, A.

RNA-Binding Proteins Hold Key

Roles in Function, Dysfunction, and

Disease. Biology 2021, 10, 366.

https://doi.org/10.3390/

biology10050366

\section{Academic Editors:}

Stylianos Ravanidis and

Epaminondas Doxakis

Received: 31 March 2021

Accepted: 21 April 2021

Published: 24 April 2021

Publisher's Note: MDPI stays neutral with regard to jurisdictional claims in published maps and institutional affiliations.

Copyright: (c) 2021 by the authors. Licensee MDPI, Basel, Switzerland. This article is an open access article distributed under the terms and conditions of the Creative Commons Attribution (CC BY) license (https:/ / creativecommons.org/licenses/by/ $4.0 /)$.
Wellcome-Wolfson Institute for Experimental Medicine, School of Medicine, Dentistry and Biomedical Sciences, Queen's University Belfast, 97 Lisburn Road, Belfast BT9 7BL, UK; s.kelaini@qub.ac.uk (S.K.); cchan10@qub.ac.uk (C.C.); vcornelius01@qub.ac.uk (V.A.C.)

* Correspondence: a.margariti@qub.ac.uk

Simple Summary: Chronic hyperglycemia manifests in a variety of different micro- and macrovascular disorders such as diabetes mellitus and cardiovascular disease and has been shown to have links to post-transcriptional dysregulation. Equally, the development and progress of other devastating disorders such as tumorigenesis and neurodegenerative disease have also been associated with dysfunction of molecules involved in epigenetics such as RNA-binding proteins. Recent advances, especially on an analytical systemic level, have revealed new roles for these proteins and their contribution in maintaining the balance between normal function and dysfunction/disease.

Abstract: RNA-binding proteins (RBPs) are multi-faceted proteins in the regulation of RNA or its RNA splicing, localisation, stability, and translation. Amassing proof from many recent and dedicated studies reinforces the perception of RBPs exerting control through differing expression levels, cellular localization and post-transcriptional alterations. However, since the regulation of RBPs is reliant on the micro-environment and events like stress response and metabolism, their binding affinities and the resulting RNA-RBP networks may be affected. Therefore, any misregulation and disruption in the features of RNA and its related homeostasis can lead to a number of diseases that include diabetes, cardiovascular disease, and other disorders such as cancer and neurodegenerative diseases. As such, correct regulation of RNA and RBPs is crucial to good health as the effect RBPs exert through loss of function can cause pathogenesis. In this review, we will discuss the significance of RBPs and their typical function and how this can be disrupted in disease.

Keywords: RNA binding protein; splicing factor; translation regulator; disease; stress granules

\section{Introduction}

RNA-binding proteins (RBPs) are critical RNA regulators responsible for modulating post-transcriptional events in the cell. RBPs can recognize and interact with binding motifs called RNA recognition motifs (RRM) and/or RNA structure to form ribonucleoprotein (RNP) complexes for the regulation of various RNA processes such as RNA stability, alternative pre-mRNA splicing, mRNA decay, translocation, post-translational nucleotide modifications, and RNA localization (Figure 1) [1,2]. 


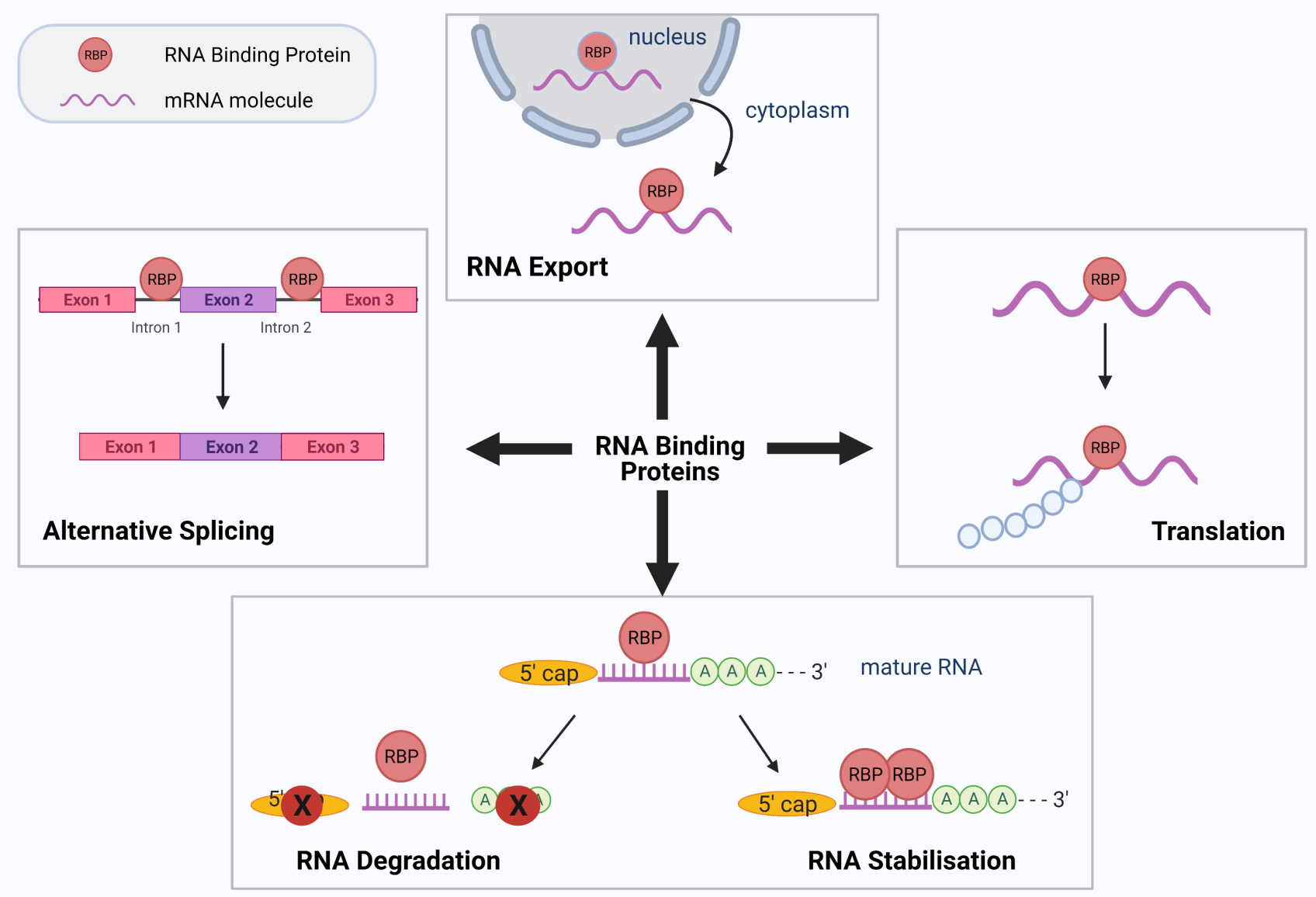

Figure 1. Schematic diagram summarizing the various roles of RNA binding proteins (RBPs). RBPs have numerous roles in RNA processing and translation. Four such functions of RBPs are demonstrated diagrammatically above: alternative splicing, RNA export, protein translation, RNA degradation, and stabilization. Figure created using Biorender.com.

The mRNA life cycle from newly transcribed mRNA molecules to the generation of functioning mature mRNA transcripts is an intricate system which is governed by many different RBPs. In the human genome there are at least 1200 verified RBPs as well as several newly discovered ones [3]. RBP-RNA binding occurs at the RNA binding domain (RBD) which are found within the coding sequences (intron and exon domains), $5^{\prime}$ untranslated regions (5'UTR) and $3^{\prime}$ untranslated regions ( $\left.3^{\prime} \mathrm{UTR}\right)$ of RNA. RBP binding produces various effects on RNA splicing, transcription efficiency, stabilization, and more. For example, RBPs can interact with target binding sites within the coding region to facilitate alternative splicing while RBP-RNA interactions within the $3^{\prime}$ UTR domain can inhibit or induce mRNA decay, as well as mediate RNA stabilization. Conversely, lack of RBP binding to 3'UTR targets can destabilize mRNA molecules [4]. In addition, RBPs have key regulatory roles in important RNA maturation events such as polyadenylation, the addition of the $5^{\prime}$ cap, and pre-mRNA alternative splicing, all of which are vital for the expression of functioning, mature RNA. However, RBPs can initiate degradation and RNA decay through deadenylating enzymes to remove the $3^{\prime}$ poly-A tail, and decapping enzymes to remove the $5^{\prime}$ cap, therefore enabling RNA degradation [5]. Several RBPs have been implicated in human disease, from vascular conditions such as diabetes and heart disease to cancer and neurogenerative disorders. Here, we showcase selected examples of RBP dysregulation and their subsequent contribution to the development of human diseases (Table 1). 
Table 1. Table displaying disorders arising from RNA-binding protein (RBP) dysfunction. Dysregulation of RBPs can lead to diseases such as cardiovascular and peripheral vascular disease, diabetes, cancer, and neurodegenerative disease.

\begin{tabular}{|c|c|c|c|}
\hline \multicolumn{2}{|c|}{ RNA Binding Protein } & \multirow{2}{*}{ Functions in Pathology } & \multirow{2}{*}{$\begin{array}{c}\text { Disease Outcomes } \\
\text { Diabetic cardiomyopathy via alternative } \\
\text { splicing defects of genes important for healthy } \\
\text { cardiac regulation }\end{array}$} \\
\hline $\begin{array}{l}\text { RNA Binding Fox-1 } \\
\text { Homolog } 2\end{array}$ & RBFOX2 & & \\
\hline $\begin{array}{l}\text { Human Antigen R/ELAV } \\
\text { Like RNA Binding Protein } 1\end{array}$ & HuR/ELAV1 & $\begin{array}{l}\text { Inducement of RNA stabilization and } \\
\text { promotion of mRNA translation via } \\
\text { binding to } 3^{\prime} \text { UTR AREs }\end{array}$ & $\begin{array}{l}\text { Diabetic nephropathy via binding of target } \\
\text { genes such as SNAIL and FOS which } \\
\text { contribute to EMT and nephropathy in } \\
\text { diabetic conditions }\end{array}$ \\
\hline Tristetraprolin & TTP & $\begin{array}{l}\text { Inducement of RNA destabilisation } \\
\text { and decay via binding to } 3^{\prime} \text { UTR AREs }\end{array}$ & $\begin{array}{l}\text { Atherosclerosis progression, and inflammation } \\
\text { in TTP-deficient ECs }\end{array}$ \\
\hline Quaking & QKI & Enablement of mRNA degradation & $\begin{array}{l}\text { Diabetic EC dysfunction via degradation of } \\
\text { targets such as VE-cadherin }\end{array}$ \\
\hline $\begin{array}{l}\text { U2 Small Nuclear RNA } \\
\text { Auxiliary Factor } 1\end{array}$ & U2AF1 & $\begin{array}{l}\text { Mutations associated with disruption } \\
\text { to pre-mRNA alternative splicing }\end{array}$ & $\begin{array}{l}\text { Cancer progression via differential splicing of } \\
\text { cancer-relevant gene targets in MDS }\end{array}$ \\
\hline $\begin{array}{l}\text { Mutated Splicing Factor 3b } \\
\text { Subunit } 1\end{array}$ & SF3B1 & $\begin{array}{l}\text { Mutations associated with disruption } \\
\text { to pre-mRNA alternative splicing }\end{array}$ & Cancer progression in CLL \\
\hline $\begin{array}{l}\text { Negative Elongation Factor } \\
\text { E }\end{array}$ & NELFE & $\begin{array}{l}\text { Inducement of mRNA stabilisation of } \\
\text { protooncogenes }\end{array}$ & $\begin{array}{l}\text { Cancer progression by stabilization of } \\
\text { MYC-associated genes and MYC signalling in } \\
\text { HCC }\end{array}$ \\
\hline Lin-28 Homolog A & LIN28 & $\begin{array}{l}\text { Blocking of miRNA processing and } \\
\text { maturation }\end{array}$ & $\begin{array}{l}\text { Cancer development and progression via } \\
\text { promotion of several cellular functions } \\
\text { involved in cell proliferation, invasion, and } \\
\text { angiogenesis }\end{array}$ \\
\hline $\begin{array}{l}\text { Cytoplasmic } \\
\text { Polyadenylation Element } \\
\text { Binding Protein } 1\end{array}$ & CPEB1 & $\begin{array}{l}\text { Enablement of mRNA localization } \\
\text { Inducement of alternative } \\
\text { polyadenylation }\end{array}$ & $\begin{array}{l}\text { Cancer progression via promotion of cancer } \\
\text { cell migration } \\
\text { CPEB1 deficiency associated with cancer } \\
\text { development }\end{array}$ \\
\hline $\begin{array}{l}\text { Insulin Like Growth Factor } \\
2 \text { MRNA Binding Protein } 1\end{array}$ & IGF2BP & $\begin{array}{l}\text { Inducement of mRNA stability, } \\
\text { translocation, and translation }\end{array}$ & $\begin{array}{l}\text { Cancer progression via stabilization and } \\
\text { translation of cancer-relevant mRNA }\end{array}$ \\
\hline $\begin{array}{l}\text { Eukaryotic Translation } \\
\text { Initiation Factor } 4 \mathrm{E}\end{array}$ & eIF4E & Regulation of mRNA translation & $\begin{array}{l}\text { Promotion of tumorigenesis by translation of } \\
\text { protooncogenes, and malignancy-related } \\
\text { factors }\end{array}$ \\
\hline $\begin{array}{l}\text { Serine/Arginine-Rich } \\
\text { Splicing Factor } 1\end{array}$ & SRSF1 & Regulation of alternative splicing & $\begin{array}{l}\text { Cancer progression via splicing of } \\
\text { protooncogenes and tumor suppressor genes }\end{array}$ \\
\hline Ataxin 2 & ATXN2 & \multirow{4}{*}{$\begin{array}{l}\text { Mutations in genes elevated in } \\
\text { neurodegenerative disorder }\end{array}$} & \multirow{4}{*}{$\begin{array}{l}\text { Progression and development of } \\
\text { neurodegenerative disorder ALS }\end{array}$} \\
\hline $\begin{array}{l}\text { Heterogenous Nuclear } \\
\text { Ribonucleoprotein A1 }\end{array}$ & hnRNPA1 & & \\
\hline Matrin 3 & MATR3 & & \\
\hline $\begin{array}{l}\text { TIA1 Cytotoxic Granule } \\
\text { Associated RNA Binding } \\
\text { Protein }\end{array}$ & TIA-1 & & \\
\hline $\begin{array}{l}\text { TAR DNA-binding } \\
\text { protein } 43\end{array}$ & TDP-43 & $\begin{array}{l}\text { Fragmentation and formation of } \\
\text { inclusion bodies }\end{array}$ & $\begin{array}{l}\text { Promotion of neurodegenerative disease } \\
\text { advancement in ALS }\end{array}$ \\
\hline FUS RNA Binding Protein & FUS & $\begin{array}{l}\text { Regulation of RNA translocation, and } \\
\text { localization in stress granules }\end{array}$ & $\begin{array}{l}\text { Neuronal disease onset by stress granule } \\
\text { aggregation }\end{array}$ \\
\hline $\begin{array}{l}\text { Neuro-oncological ventral } \\
\text { antigen } 1 \text { and } 2\end{array}$ & Nova 1 and 2 & Regulation of alternative splicing & POMA onset by autoantibody secretion \\
\hline $\begin{array}{l}\text { Far Upstream Element } \\
\text { Binding Protein } 1\end{array}$ & FUBP1 & Regulation of alternative splicing & $\begin{array}{l}\text { Involvement in SMA by increasing FUBP1 } \\
\text { affinity to SNF1 pre-mRNA. }\end{array}$ \\
\hline
\end{tabular}

\section{RBPs in the Pathogenesis of Diabetes and Cardiovascular Disease}

Diabetes mellitus (DM) is an increasingly prevalent global health burden [6]. DM is a lifelong disease, characterized by chronic hyperglycemia. DM is highly associated with an increased risk of debilitating secondary morbidities manifesting in macrovascular disease (atherosclerosis, ischemic stroke, coronary artery disease) and microvascular 
disease (diabetic retinopathy, neuropathy, and nephropathy) [7]. Close to $10 \%$ of worldwide diabetes diagnoses are categorized as Type 1 . The remaining majority are diagnosed as Type 2 [8], where cells become increasingly resistant to insulin action [9], leading to impaired glucose homeostasis with cells unable to internalize circulating blood glucose. Chronic hyperglycemia causes systemic damage to the vasculature triggering multisystemic conditions such as cardiovascular disease (CVD). Additionally, due to the frequency of CVD occurrence in diabetes, it is often considered a CVD in itself. Currently, there is no curative therapy available for diabetes-associated CVD. With rising rates of diabetes, there lies a deepening need for knowledge into the mechanisms behind hyperglycemia-related cardiovascular damage. In vascular endothelial cells (ECs), hyperglycemia has been determined to contribute to a substantial change of gene expression. Transcriptomic analytical assays have uncovered a wide variety of candidate genes implicated in cellular functions such as angiogenesis, coagulation, vascular tone, adhesion, and more. This vascular EC gene expression is tightly controlled by transcriptional and post-transcriptional regulatory mechanisms, the latter including regulation of pre-mRNA to mRNA processing, transport, decay and protein translation [10]. Precise regulation of these complex post-transcriptional modifications in the RNA network is crucial for the normal function of vascular ECs and the endothelial system. In diabetes, a plethora of RBP-regulated RNA networks are involved in the dysfunction of the vascular endothelium [11]. In this section, we will review some of the most common RBPs dysregulated in the pathogenenesis of DM and CVD and their epigenetic effects.

For instance, RNA Binding Fox-1 Homolog 2 (RBFOX2), regulates alternative splicing and is upregulated in the diabetic heart, controlling splicing of genes involved in diabetic cardiomyopathy by binding to target RNA motifs associated with protein trafficking and cell apoptosis [12,13]. Additionally, Human Antigen R (HuR) also known with its alternative name ELAVL1, is a ubiquitously expressed RBP, which is upregulated and activated under high glucose and in diabetes [14]. HuR binds to specific domains known as AU-rich elements (ARE) in the $3^{\prime}$ UTRs of target genes that play a role in inflammation and diabetic nephropathy [15-17]. Once it is activated, it translocates to the cytoplasm to bind its mRNA targets affecting their stability and translation [18]. Tristetraprolin (TTP) binds to $3^{\prime}$ UTR ARE region that results in mRNA destabilization and decay [19]. TTP is minimally expressed in healthy aortas but significantly heightened in affected macrophage foam cells as well as ECs of atherosclerotic lesions [20]. In another example, Quaking (QKI), an RBP member of the Signal Transduction and Activation of RNA (STAR) protein family and some of its isoforms - namely QKI5, QKI6, QKI7-have been associated with vascular development [19]. In our lab, we have previously shown that, compared to controls, there are reduced QKI5 levels in cardiac vessels of diabetic mice, therefore displaying the key status of QKI5 within the diabetic framework of vessel dysfunction. In addition, as we have also reported [21], QKI5 played a crucial role in differentiating ECs from induced pluripotent stem cells (iPSCs) via stabilization of VE-cadherin and Vascular Endothelial Growth Factor Receptor 2 (VEGFR2) activation through Signal Transducer and Activator of Transcription 3 (STAT3) signaling. Furthermore, we showed QKI-7 to bind and promote mRNA target degradation such as of VE-cadherin, while the knockdown of QKI7 in a diabetic mouse model of hindlimb ischemia significantly restored reperfusion and blood flow in vivo [22].

RBPs are also implicated in the dysfunction of ECs under diabetic conditions in relation to their association with non-protein coding RNAs (ncRNAs), which include long noncoding RNAs (lncRNAs). The latter are, in fact, responsible for the preponderance of gene transcripts and act as positive or negative regulators based on their interactions with RBPs [23]. The importance of the RBP and lncRNAs system as a fundamental part of healthy cellular function through regulation of epigenetic machineries is largely acknowledged [24]. In recent years, data from numerous studies has showed a correlation between abnormal levels of lncRNAs and different diseases such as diabetes. For example, the levels of Metastasis-Associated Lung Adenocarcinoma Transcript 1 (MALAT1) were 
significantly elevated both in vivo (in retinal ECs of a streptozotocin (STZ) diabetic rat model) and in vitro when human umbilical vein endothelial cells (HUVECs) were treated with high glucose. Short hairpin RNA (shRNA) knockdown of MALAT1 reduced vascular dysfunction and also decreased reactive oxygen species (ROS) levels in hyperglycemic ECs signifying its connection with diabetic retinopathy and EC dysfunction $[25,26]$. Similarly, under diabetic conditions, myocardial infarction associated transcript (MIAT) lncRNA is elevated, as data from studies of diabetic retinas and high-glucose treated ECs have shown. Furthermore, knockdown of MIAT reversed the dysfunction [27]. More such examples of lncRNA dysregulation in diabetic conditions exist as in the case of increased antisense noncoding RNA in the INK4 Locus (ANRIL) [21] promoting pathogenic angiogenesis [28] or in the case of Maternally Expressed Gene 3 (MEG3), which had reduced levels in the retinal ECs as shown in an STZ model of diabetic mice [29].

The above examples demonstrate the close association of lncRNAs and RBPs and the importance of this relationship in diabetic pathogenesis. At the same time, it is becoming clearer that advances in RNA biology uncover more roles for RBPs in the progression of diabetes where the dysregulation of RBPs controlling alternative splicing, RNA decay, and destabilization can have disastrous downstream effects on cardiovascular genes.

\section{RBPs and Their Role in Cancer Development and Progression}

RBPs are tightly associated with tumorigenesis [30] and dysregulated RBPs have been reported by many studies to play a critical role in cancer [31]. For example, mutations in the splicing factor U2 Small Nuclear RNA Auxiliary Factor 1 (U2AF1), affects premRNA splicing and contributes to the progression of cancer such as myelodysplasia (MDS) [32]; even with a single mutation such as S34F [33], which affects hundreds of mRNAs. In another example, Splicing Factor 3b Subunit 1 (SF3B1) has been found to be mutated in a lot of patients suffering from chronic lymphocytic leukemia (CLL) [34,35]. Mutated SF3B1, along with mutated U2AF1, Serine and Arginine Rich Splicing Factor 2 (SRSF2) and Zinc Finger CCCH-Type, RNA Binding Motif And Serine/Arginine Rich 2 (ZRSR2) genes, is also very frequently observed in MDS [36] and has been linked to poor survival rate [34]. Negative Elongation Factor E (NELFE) was also reported to promote hepatocellular carcinoma (HCC) progression by augmenting MYC signaling and selectively controlling MYC-associated genes [37].

Despite the extensive studies on a selection of individual RBPs, the role of RBPs in cancer continue to appear obscure and more studies are still needed to define in a clearer way the landscape of RBP expression in human cancers. Consequently, recent studies are now focusing on integrating the expression profiles of multiple RBPs to universally and analytically examine their mechanism of action in many different cancers [33]. Studies focusing on building a thorough expression profile of several hundreds of RBPs in 16 different types of human cancer uncovered that RBPs are primarily upregulated in cancers compared to downregulated ones and that their dysregulation can be influenced by the tumor microenvironment. Specifically, the number of RBPs found to be consistently upregulated in cancer were 109 compared to downregulated RBPs which were just 41 [38]. As it is widely known, an mRNA's destiny is primarily defined by its interactions with RBPs. In cancer, dysregulation in the RBP-mediated RNA stability, localization, and posttranscriptional events can have an effect in cancer profiles [39].

Variations in an RBP's expression or localization has the capacity to impact oncogene expression levels or those of tumor-suppressor genes. They can also influence genes important to genome stability. As a result, different transcriptomic and cellular phenotypes arise under the influence of RBP-centered gene regulation, such as differences in proliferation or apoptosis, as well as in other functions like angiogenesis or epithelial to mesenchymal transition (EMT). Eventually all these can, in turn, give rise to different profiles of cancer invasion and metastasis as well as different cancer prognoses. It is therefore becoming more and more apparent that RBPs can act as prospective targets for future cancer treatments [40]. 
One of the key roles of RBPs lies in their regulatory involvement in micro-RNA (miRNA) biogenesis and subsequent maturation. The close relationship between dysregulation of miRNA processing and RBP expression can lead to mRNAs alterations that can contribute to cancer [41]. For example, the RBP LIN28 and its related Lin28/let-7 pathway can lead to cancer development and progression by promoting increased cell proliferation, invasion, or angiogenesis [42]. The cellular areas where mRNA or noncoding RNA such as lncRNA are localized can also alter protein expression; cancer associated RBPs bind to these RNA targets to coordinate to guide localization and translation $[43,44]$. For instance, the RBP Cytoplasmic Polyadenylation Element Binding Protein 1 (CPEB1) controls Zonula occludens-1 (ZO-1) mRNA localization. When there are diminished CPEB1 levels, this decrease causes ZO-1 mRNA to scatter within the cell causing epithelial cell polarity impairment [45], which is linked to metastatic risk [46]. RBPs can also exert effect on mRNA stability. The latter relies on its $5^{\prime}$-terminal 7-methylguanosine cap as well as its $3^{\prime}$ poly(A) tail, both of which protect mRNAs from decay and also stimulate translation [47]. mRNA decay can transpire through decapping or deadenylation of the poly(A) tail) of the mRNA targets which are transported to cytoplasmic aggregations such as stress granules [48]. In cancer, RBPs, including HuR, TTP, and Insulin Like Growth Factor 2 MRNA Binding Protein 1 (IGF2BP), can affect the stability of target RNAs [49].

Another characteristic of RBP dysregulation in cancer is gene regulation and translational control. RBPs, by binding to the $5^{\prime}-$ or $3^{\prime}$-UTR of RNA, are implicated in translation in a varying binding capacity which affects translation efficiency [50]. For example, Eukaryotic Translation Initiation Factor 4E (eIF4E), which has increased levels in cancer, promotes tumorigenesis through mRNA-mediated cellular functions that include, for example, proliferation or angiogenesis [51]. Alternative splicing also constitutes a vital process through which dysregulated RBPs may exert an effect in cancer development through different mRNA splice variants resulting in protein diversity and aberrant splicing forms in cancer [52]. Such modifications can enhance the action of oncogenes or, conversely, quell tumor-suppressive genes [53,54]. For example, SRSF1 is known to modify the splicing of the protooncogene Recepteur d'origine nantais (Ron) as well as the tumor suppressor gene Bridging Integrator 1 (BIN1) [54,55]. Lastly, alternative polyadenylation (APA) of target mRNAs, a process involving the modification of $3^{\prime} U T R$ length, can be seen in cancer-related genes (oncogenes and tumor suppressors), promoting cancer development by altering their expression through RBP mediated regulation [56]. RBPs specifically regulate APA by enlisting or competing with other proteins within the polyadenylation machinery [57]. CPEB1, for example, alters the $3^{\prime}$-UTR length of target mRNAs and, in turn, modifies the associated gene expression signatures. As a result, decreased CPEB1 expression lengthens the poly $(\mathrm{A})$ tail resulting in increased Matrix Metallopeptidase 9 (MMP9) mRNA translation in breast cancer [46].

\section{RBPs and Their Role in Neurodegenerative Disease}

Even though the functional mechanisms of RBPs are still not fully elucidated, more recent evidence has indicated that RBPs are key players in the preservation and integrity of neurons. Any defects and alterations in the function of RBPs and in RNA metabolism arising from mutations can cause several neurodegenerative diseases that affect the central nervous system, such as frontotemporal lobar degeneration (FTD), amyotrophic lateral sclerosis (ALS), fragile X syndrome (FXS), or spinal muscular atrophy (SMA). Other diseases usually associated with aging and that can be affected by RBP dysregulation include Alzheimer's disease (AD) and Parkinson's disease (PD). The increasing aging global population has additionally resulted in an increase in the number of worldwide dementia cases, despite a relative decrease in developed countries [58]. In the case of ALS for instance, analytical investigations have revealed a strong genetic relationship between mutations of RBP-encoding genes like Ataxin 2 (ATXN2), Heterogeneous Nuclear Ribonucleoprotein A1 (hnRNPA1), Matrin 3 (MATR3) or TIA1 Cytotoxic Granule Associated RNA Binding Protein (TIA-1), and development and progression of the disease [59,60]. Likewise, in FTD, which 
shares many common characteristics with ALS [61,62], fragmentation of RBPs such as TAR DNA-binding protein 43 (TDP-43) in the cytoplasm, has been shown to advance the onset of the disease $[63,64]$. In the case of SMA, a serious motor neuron disease, small molecule drug analogs of RG-7916 (SMN-C2 or -C3) were found to selectively regulate alternative splicing of Survival of Motor Neuron 2 (SMN2) by binding to the gene's pre-mRNA and increasing the affinity of the RBP Far Upstream Element Binding Protein 1 (FUBP1) to it [65]. Another neurological syndrome Paraneoplastic opsoclonus-myoclonus ataxia (POMA) is caused by autoantibody secretion against the RBP neuro-oncological ventral antigen 1 and 2 (Nova 1, Nova 2) [66], which are neuron-specific found in the nucleus and regulate RNA splicing [67]. In another example, myotonic dystrophy (MD) which commonly presents in patients as muscular degeneration, is also characterized by aberrant RNA splicing; CUG triplet repeat (CUGBP) has been specifically linked to MD through its interaction with myotonic dystrophy protein kinase (DMPK) mRNA [68].

These types of neurological diseases usually present with aggressive and irreversible characteristics that can prove devastating, and on many occasions even fatal, such as permanent neuron loss, which involves neural cells such as microglia and astrocytes. In neurodegenerative disease a great deal of attention has been concentrated on the different protein aggregates; however, it is of utmost importance to also focus on additional avenues that involve RNA and post transcriptional modifications as a pathogenic component of neurodegenerative disease [69,70]. In neurons, looking at the high incidence of RNA transport granules may explain why RBP dysfunction can initiate neuronal disease. The RNA granules creation and aggregate formation in a cell's cytoplasm has been considered to be pathogenic in nature. During cellular stress, RBPs like those with low complexity domains (LCD), such as FUS RNA binding protein (FUS) or hnRNPA1 translocate from the nucleus, where they are usually present, to the cytoplasm and localize in granules [71,72]. Once there, they transiently form droplet organelles [73] with different functions based on their components [74]. Higher RBP concentrations can change these functions and lead to the polymerization of LCDs and the creation of amyloid-like fibers and insoluble aggregates [75]. Studies on these aggregates are giving rise to hypotheses that in neurons affected by dementias such as ALS or AD, disturbances such as mutations in RBPs play a role in impairing their regular physiological function. In the case of dementias such as $\mathrm{AD}$, a study on RBP-containing stress granules showed their elevated accumulation in the brains of transgenic mice used as a model of tauopathy [76]. Furthermore, these granules have an interconnecting role with miRNAs, since the latter interact with RBP to regulate protein translation [77], adding an additional layer of complexity.

In general, mutations in the proteins associated with disease increase their propensity for higher aggregation, shifting the balance towards increased creation of more stable, less soluble and, thus, more persistent, stress granules, including secondary granules, which are usually associated with disease. Equally, approaches in neuroprotective therapeutics are directing their efforts against pathogenesis by reducing the creation of stress granules and restoring the balance [78].

\section{RBP-Based Therapeutics and Future Directions}

It is widely known that RBPs are crucial players in epigenetic post-transcriptional gene regulation. A plethora of studies has revealed the interconnection between RBPs and mRNA including a complex network of fifty thousand interactions [3]. In Figure 2, a summary of RBP targeting therapeutic strategies is presented. Since these RBP-mediated RNA networks can drive vascular pathogenesis, steering therapeutic investigations towards the discovery of putative candidate RBPs is the way forward towards treating vascular abnormalities and endothelial dysfunction prevalent in diabetes and heart disease. It is noteworthy that, even individually, RBPs can be utilized as potential targets for prospective treatments. As such, the RBP TTP is protective in inflammatory conditions involving diabetes and atherosclerosis by acting as a mediator for pro-inflammatory cytokine degradation [79]. For example, in the case of increased expression of tumor necrosis factor 
(TNF), a hallmark indicator of chronic inflammation, TNF homeostasis is regulated by TTP and, more specifically, by a post transcriptional regulatory positive or negative feedback loop [80]. An additional illustration of a prospective treatment strategy on the subject of heart disease is Poly $(\mathrm{C})$-binding protein 2 (PCBP2) which was shown to be reduced in the diseased heart in humans as well as in hypertrophied hearts in mice. Moreover, its silencing in neonatal cardiomyocytes, in particular, supported angiotensin II (Ang II)-induced hypertrophy, whilst the reverse effect was achieved through its overexpression $[81,82]$.

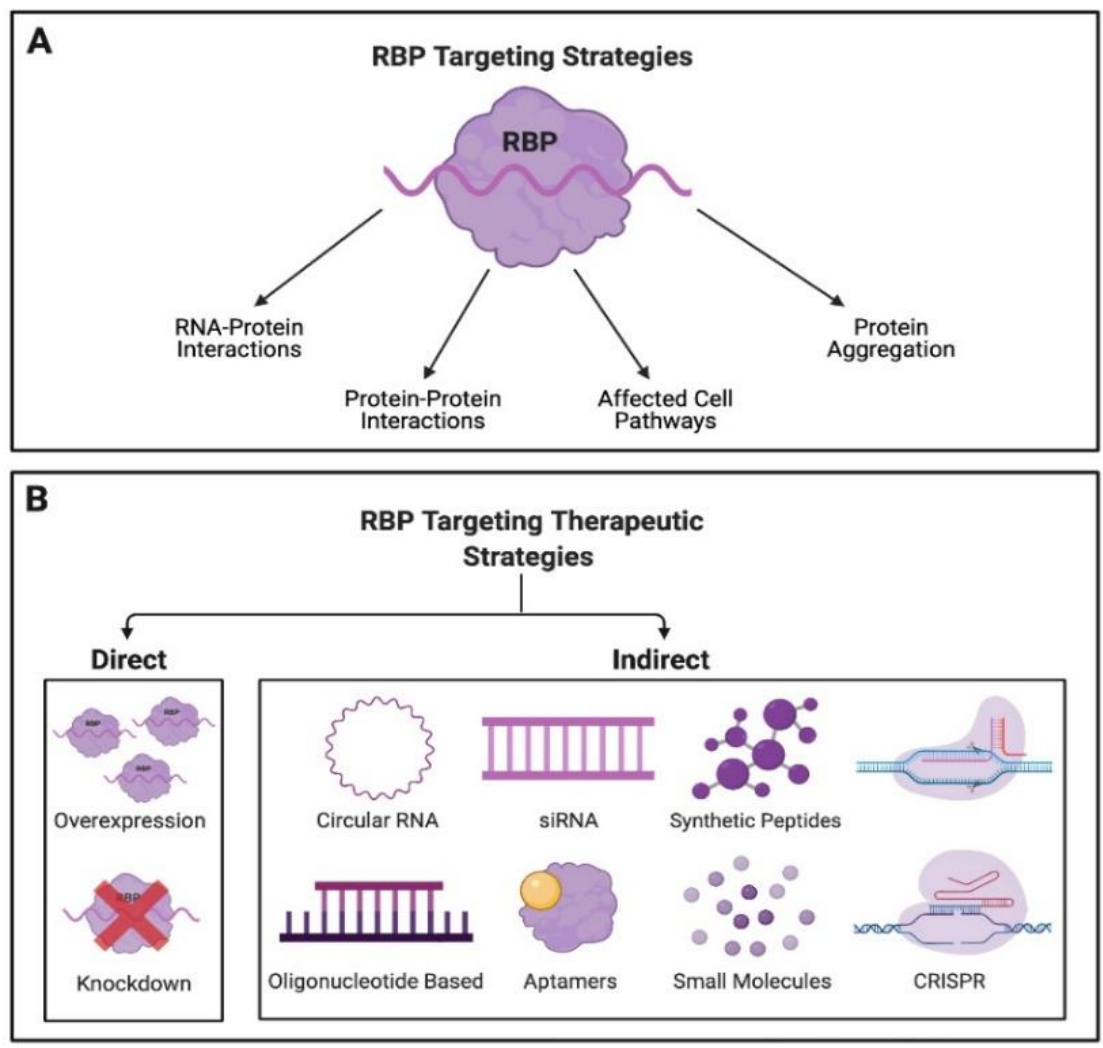

Created in BioRender.com bio

Figure 2. (A) Schematic diagram displaying RBP targeting strategies that may involve RNA-protein or protein-protein interactions, protein aggregation and cell pathways. (B) Current RBP-based targeting therapeutic strategies focus on either the manipulation of a specific RBP or an RBP-RNA interaction and so can be categorised as either direct or indirect approaches, respectively. Direct therapeutic strategies revolve around the knockdown or overexpression of a particular RBP. Indirect approaches, on the other hand, including the use of circular RNA, siRNA, synthetic peptides, oligonucleotide based, aptamers, small molecules, and CRISPR, can be designed to either inhibit the interaction of an RBP with RNA by inducing degradation, to suppress enzymatic activity, to block post transcriptional modifications or through binding to outcompete a chosen RBP. Figure created using Biorender.com.

Regarding cancer therapeutics, the role of RBP dysfunction in its initiation and spread is well known. What is not fully understood, however, is how to wholly and safely utilize the available RBP based approaches. Previously, it was not thought possible to target RBPs in cancer due to not being able to target them directly with specific drugs. Lately, however, it is becoming increasingly clearer that it might be feasible to target RBPs indirectly and with varied approaches. These approaches include the use of small molecules, which is the most common RBP-targeting tactic. Small molecules can hinder RBP-RNA interaction by, for example, binding to RBDs such as in the case of small molecules targeting eIF4E [83]. Another anti-cancer strategy involves the use of an oligonucleotide-based strategy which 
includes short antisense oligonucleotides (ASOs), a few of which have previously been approved for the treatment of other diseases such as hyperlipidemias or viral infections [84]. Currently, no such drugs to our knowledge are approved for the treatment of cancer, however, the potential of many are presently being evaluated in pre-clinical and clinical trials. For example, ISIS 183750 targeting eIF4E has been tested in clinical trials in patients with advanced stage colorectal cancer [85]. Furthermore, therapies involving siRNA have been employed for the targeting of RBPs such as HuR, a great a potential target in ovarian cancer [86]. Other strategies used as anti-cancer agents include aptamers with a mechanism similar to antibodies. Consequently, a clinical study found that addition of AS1411 to chemotherapy regimen in AML patients showed improved response [87]. Additionally, various synthetic peptides that target and bind RBPs such as elF4E have been developed and shown to exert strong antitumor effects in mouse models of ovarian cancer [83]. Moreover, circular RNAs (circRNAs) have been shown to act as RBP 'sponges' such as (Poly(A) Binding Protein Nuclear 1 (PABPN1)-derived circRNA binding to HuR [88,89]. Finally, whilst the Clustered Regularly Interspaced Short Palindromic Repeats/CRISPR Associated Protein 9 (CRISPR/Cas9) system has not been used in cancer treatment, yet it similarly holds great promise as a future anti-cancer approach [90].

In current neurodegenerative treatment strategies, typical therapeutic approaches are usually focused on limiting the generation of toxic aggregates in the cytoplasm. These approaches include activation of the heat shock response (HSP), utilization of HSP104 disaggregases or regulation of autophagy. For example, HSP104 disaggregase corrected many [PSI+] prions which are based on amyloid formation [91] while its modified version improved the mode of action compared to wild-type, efficiently suppressing TDP-43 or FUS based toxicity in yeast cells [92]. In rat neurons overexpressing TDP-43, another HSP, the Heat Shock Factor 1 (HSF1), prevented cytoplasmic aggregation of TDP-43 and also reduced toxicity in TDP-43 overexpressing human bone marrow neuroblasts [93]. Likewise, data from studies on autophagy activators showcased that they have the capability to rescue motor dysfunction in a transgenic mouse model of FTD. In a similar fashion, autophagy induction boosted TDP-43 turnover and enhanced the survival of neuronal cells in models of ALS $[94,95]$. These approaches offer a prospective therapeutic strategy through the elimination of toxic cytoplasmic aggregates. However, until the full elucidation of the mechanisms that trigger RBP based neurogenerative disease have been uncovered, it is challenging to define with absolute certainty the best therapeutic interventions delivering the biggest therapeutic effect in patients.

\section{Conclusions}

In conclusion, disruption to the function of RBPs and the ensuing post-transcriptional dysregulation in gene expression can lead to significant events in the development and progression of distinct human diseases. Any associated therapeutic approaches are still limited by the ambiguity surrounding the roles of RBPs which have not been fully understood yet and are still under investigation, given the complexity of their interaction with other cellular networks, pathways, and processes involved in disease. Nevertheless, newly emerging technologies that involve high throughput analyses allow for the uncovering and deciphering of further interconnections and the discovery of new RBP and RNA targets. The results of such analysis will shed light on the mechanisms underpinning human disorders that currently plague patients worldwide and provide assurance on the efficacy and safety of any novel corrective options. Future medicinal advances will grace us with the possibility of using these remedial strategies in a clinical setting.

Funding: This research was funded by British Heart Foundation grant number PG/18/29/33731.

Institutional Review Board Statement: Not applicable.

Informed Consent Statement: Not applicable.

Conflicts of Interest: The authors declare no conflict of interests. 


\section{References}

1. Liu-Yesucevitz, L.; Bassell, G.J.; Gitler, A.D.; Hart, A.C.; Klann, E.; Richter, J.D.; Warren, S.T.; Wolozin, B. Local RNA translation at the synapse and in disease. J. Neurosci. 2011, 31, 16086-16093. [CrossRef] [PubMed]

2. Van Nostrand, E.L.; Freese, P.; Pratt, G.A.; Wang, X.; Wei, X.; Xiao, R.; Blue, S.M.; Chen, J.Y.; Cody, N.A.L.; Dominguez, D.; et al. A large-scale binding and functional map of human RNA-binding proteins. Nature 2020, 583, 711-719. [CrossRef] [PubMed]

3. Quattrone, A.; Dassi, E. The Architecture of the Human RNA-Binding Protein Regulatory Network. iScience 2019, 21, 706-719. [CrossRef] [PubMed]

4. Moore, K.S.; von Lindern, M. RNA Binding Proteins and Regulation of mRNA Translation in Erythropoiesis. Front. Physiol. 2018, 9, 910. [CrossRef] [PubMed]

5. Dhatariya, K. Diabetes: The place of new therapies. Adv. Endocrinol. Metab. 2018, 10, 2042018818807599. [CrossRef]

6. Saeedi, P.; Petersohn, I.; Salpea, P.; Malanda, B.; Karuranga, S.; Unwin, N.; Colagiuri, S.; Guariguata, L.; Motala, A.A.; Ogurtsova, K.; et al. Global and regional diabetes prevalence estimates for 2019 and projections for 2030 and 2045: Results from the International Diabetes Federation Diabetes Atlas, 9(th) edition. Diabetes Res. Clin. Pract. 2019, 157, 107843. [CrossRef]

7. Leon, B.M.; Maddox, T.M. Diabetes and cardiovascular disease: Epidemiology, biological mechanisms, treatment recommendations and future research. World J. Diabetes 2015, 6, 1246-1258. [CrossRef]

8. Mobasseri, M.; Shirmohammadi, M.; Amiri, T.; Vahed, N.; Hosseini Fard, H.; Ghojazadeh, M. Prevalence and incidence of type 1 diabetes in the world: A systematic review and meta-analysis. Health Promot. Perspect 2020, 10, 98-115. [CrossRef]

9. Wilcox, G. Insulin and insulin resistance. Clin. Biochem. Rev. 2005, 26, 19-39.

10. Whelan, J.T.; Hollis, S.E.; Cha, D.S.; Asch, A.S.; Lee, M.H. Post-transcriptional regulation of the Ras-ERK/MAPK signaling pathway. J. Cell. Physiol. 2012, 227, 1235-1241. [CrossRef]

11. Scott, L.J.; Mohlke, K.L.; Bonnycastle, L.L.; Willer, C.J.; Li, Y.; Duren, W.L.; Erdos, M.R.; Stringham, H.M.; Chines, P.S.; Jackson, A.U.; et al. A genome-wide association study of type 2 diabetes in Finns detects multiple susceptibility variants. Science 2007, 316, 1341-1345. [CrossRef] [PubMed]

12. Nutter, C.A.; Jaworski, E.A.; Verma, S.K.; Deshmukh, V.; Wang, Q.; Botvinnik, O.B.; Lozano, M.J.; Abass, I.J.; Ijaz, T.; Brasier, A.R.; et al. Dysregulation of RBFOX2 Is an Early Event in Cardiac Pathogenesis of Diabetes. Cell Rep. 2016, 15, 2200-2213. [CrossRef] [PubMed]

13. Brosseau, J.P.; Lucier, J.F.; Nwilati, H.; Thibault, P.; Garneau, D.; Gendron, D.; Durand, M.; Couture, S.; Lapointe, E.; Prinos, P.; et al. Tumor microenvironment-associated modifications of alternative splicing. RNA 2014, 20, 189-201. [CrossRef]

14. Jeyabal, P.; Thandavarayan, R.A.; Joladarashi, D.; Suresh Babu, S.; Krishnamurthy, S.; Bhimaraj, A.; Youker, K.A.; Kishore, R.; Krishnamurthy, P. MicroRNA-9 inhibits hyperglycemia-induced pyroptosis in human ventricular cardiomyocytes by targeting ELAVL1. Biochem. Biophys. Res. Commun. 2016, 471, 423-429. [CrossRef] [PubMed]

15. Liu, S.; Huang, Z.; Tang, A.; Wu, X.; Aube, J.; Xu, L.; Xing, C.; Huang, Y. Inhibition of RNA-binding protein HuR reduces glomerulosclerosis in experimental nephritis. Clin. Sci. 2020, 134, 1433-1448. [CrossRef] [PubMed]

16. Shang, J.; Zhao, Z. Emerging role of HuR in inflammatory response in kidney diseases. Acta Biochim. Biophys. Sin. 2017, 49, 753-763. [CrossRef] [PubMed]

17. Shi, Q.; Lee, D.-Y.; Féliers, D.; Abboud, H.E.; Bhat, M.A.; Gorin, Y. Interplay between RNA-binding protein HuR and Nox4 as a novel therapeutic target in diabetic kidney disease. Mol. Metab. 2020, 36, 100968. [CrossRef]

18. Govindaraju, S.; Lee, B.S. Adaptive and maladaptive expression of the mRNA regulatory protein HuR. World J. Biol. Chem. 2013, 4,111-118. [CrossRef]

19. Strawbridge, R.J.; Dupuis, J.; Prokopenko, I.; Barker, A.; Ahlqvist, E.; Rybin, D.; Petrie, J.R.; Travers, M.E.; Bouatia-Naji, N.; Dimas, A.S.; et al. Genome-Wide Association Identifies Nine Common Variants Associated With Fasting Proinsulin Levels and Provides New Insights Into the Pathophysiology of Type 2 Diabetes. Diabetes 2011, 60, 2624-2634. [CrossRef]

20. Lai, W.S.; Carballo, E.; Thorn, J.M.; Kennington, E.A.; Blackshear, P.J. Interactions of CCCH Zinc Finger Proteins with mRNA: Binding of Tristetraprolin-Related Zinc Finger Proteins to Au-Rich Elements and Destabilization of mRNA. J. Biol. Chem. 2000, 275, 17827-17837. [CrossRef]

21. Congrains, A.; Kamide, K.; Ohishi, M.; Rakugi, H. ANRIL: Molecular Mechanisms and Implications in Human Health. Int. J. Mol. Sci. 2013, 14, 1278-1292. [CrossRef] [PubMed]

22. Yang, C.; Eleftheriadou, M.; Kelaini, S.; Morrison, T.; González, M.V.; Caines, R.; Edwards, N.; Yacoub, A.; Edgar, K.; Moez, A.; et al. Targeting QKI-7 in vivo restores endothelial cell function in diabetes. Nat. Commun. 2020, 11, 3812. [CrossRef]

23. He, R.-Z.; Luo, D.-X.; Mo, Y.-Y. Emerging roles of lncRNAs in the post-transcriptional regulation in cancer. Genes Dis. 2019, 6, 6-15. [CrossRef] [PubMed]

24. Yang, L.; Froberg, J.E.; Lee, J.T. Long noncoding RNAs: Fresh perspectives into the RNA world. Trends Biochem. Sci. 2014, 39, 35-43. [CrossRef]

25. Liu, J.Y.; Yao, J.; Li, X.M.; Song, Y.C.; Wang, X.Q.; Li, Y.J.; Yan, B.; Jiang, Q. Pathogenic role of lncRNA-MALAT1 in endothelial cell dysfunction in diabetes mellitus. Cell Death Dis. 2014, 5, e1506. [CrossRef]

26. Puthanveetil, P.; Chen, S.; Feng, B.; Gautam, A.; Chakrabarti, S. Long non-coding RNA MALAT1 regulates hyperglycaemia induced inflammatory process in the endothelial cells. J. Cell. Mol. Med. 2015, 19, 1418-1425. [CrossRef]

27. Yan, B.; Yao, J.; Liu, J.-Y.; Li, X.-M.; Wang, X.-Q.; Li, Y.-J.; Tao, Z.-F.; Song, Y.-C.; Chen, Q.; Jiang, Q. IncRNA-MIAT Regulates Microvascular Dysfunction by Functioning as a Competing Endogenous RNA. Circ. Res. 2015, 116, 1143-1156. [CrossRef] 
28. Zhang, B.; Wang, D.; Ji, T.-F.; Shi, L.; Yu, J.-L. Overexpression of lncRNA ANRIL up-regulates VEGF expression and promotes angiogenesis of diabetes mellitus combined with cerebral infarction by activating NF-KB signaling pathway in a rat model. Oncotarget 2017, 8, 17347-17359. [CrossRef] [PubMed]

29. Qiu, G.-Z.; Tian, W.; Fu, H.-T.; Li, C.-P.; Liu, B. Long noncoding RNA-MEG3 is involved in diabetes mellitus-related microvascular dysfunction. Biochem. Biophys. Res. Commun. 2016, 471, 135-141. [CrossRef]

30. Qin, H.; Ni, H.; Liu, Y.; Yuan, Y.; Xi, T.; Li, X.; Zheng, L. RNA-binding proteins in tumor progression. J. Hematol. Oncol. 2020, 13, 90. [CrossRef]

31. Wang, J.; Liu, Q.; Shyr, Y. Dysregulated transcription across diverse cancer types reveals the importance of RNA-binding protein in carcinogenesis. BMC Genom. 2015, 16, S5. [CrossRef]

32. Li, B.; Liu, J.; Jia, Y.; Qin, T.; Xu, Z.; Zhang, Y.; Huang, G.; Xiao, Z. Clinical Features and Biological Implications of U2AF1 Mutations in Myelodysplastic Syndromes. Blood 2017, 130, 586. [CrossRef]

33. Palangat, M.; Anastasakis, D.G.; Fei, D.L.; Lindblad, K.E.; Bradley, R.; Hourigan, C.S.; Hafner, M.; Larson, D.R. The splicing factor U2AF1 contributes to cancer progression through a noncanonical role in translation regulation. Genes Dev. 2019, 33, 482-497. [CrossRef] [PubMed]

34. Quesada, V.; Conde, L.; Villamor, N.; Ordóñez, G.R.; Jares, P.; Bassaganyas, L.; Ramsay, A.J.; Beà, S.; Pinyol, M.; Martínez-Trillos, A.; et al. Exome sequencing identifies recurrent mutations of the splicing factor SF3B1 gene in chronic lymphocytic leukemia. Nat. Genet. 2011, 44, 47-52. [CrossRef] [PubMed]

35. Wang, L.; Lawrence, M.S.; Wan, Y.; Stojanov, P.; Sougnez, C.; Stevenson, K.; Werner, L.; Sivachenko, A.; DeLuca, D.S.; Zhang, L.; et al. SF3B1 and other novel cancer genes in chronic lymphocytic leukemia. N. Engl. J. Med. 2011, 365, 2497-2506. [CrossRef]

36. Yoshida, K.; Sanada, M.; Shiraishi, Y.; Nowak, D.; Nagata, Y.; Yamamoto, R.; Sato, Y.; Sato-Otsubo, A.; Kon, A.; Nagasaki, M.; et al. Frequent pathway mutations of splicing machinery in myelodysplasia. Nature 2011, 478, 64-69. [CrossRef]

37. Dang, H.; Takai, A.; Forgues, M.; Pomyen, Y.; Mou, H.; Xue, W.; Ray, D.; Ha, K.C.H.; Morris, Q.D.; Hughes, T.R.; et al. Oncogenic Activation of the RNA Binding Protein NELFE and MYC Signaling in Hepatocellular Carcinoma. Cancer Cell 2017, 32, 101-114.e108. [CrossRef] [PubMed]

38. Zhang, B.; Babu, K.R.; Lim, C.Y.; Kwok, Z.H.; Li, J.; Zhou, S.; Yang, H.; Tay, Y. A comprehensive expression landscape of RNA-binding proteins (RBPs) across 16 human cancer types. RNA Biol. 2020, 17, 211-226. [CrossRef] [PubMed]

39. Modic, M.; Ule, J.; Sibley, C.R. CLIPing the brain: Studies of protein-RNA interactions important for neurodegenerative disorders. Mol. Cell. Neurosci. 2013, 56, 429-435. [CrossRef]

40. Kang, D.; Lee, Y.; Lee, J.-S. RNA-Binding Proteins in Cancer: Functional and Therapeutic Perspectives. Cancers 2020, 12, 2699. [CrossRef] [PubMed]

41. Van Kouwenhove, M.; Kedde, M.; Agami, R. MicroRNA regulation by RNA-binding proteins and its implications for cancer. Nat. Rev. Cancer 2011, 11, 644-656. [CrossRef]

42. Balzeau, J.; Menezes, M.R.; Cao, S.; Hagan, J.P. The LIN28/let-7 Pathway in Cancer. Front. Genet. 2017, 8, 31. [CrossRef]

43. Degrauwe, N.; Suvà, M.L.; Janiszewska, M.; Riggi, N.; Stamenkovic, I. IMPs: An RNA-binding protein family that provides a link between stem cell maintenance in normal development and cancer. Genes Dev. 2016, 30, 2459-2474. [CrossRef] [PubMed]

44. Jonas, K.; Calin, G.A.; Pichler, M. RNA-Binding Proteins as Important Regulators of Long Non-Coding RNAs in Cancer. Int. J. Mol. Sci. 2020, 21, 2969. [CrossRef]

45. Nagaoka, K.; Udagawa, T.; Richter, J.D. CPEB-mediated ZO-1 mRNA localization is required for epithelial tight-junction assembly and cell polarity. Nat. Commun. 2012, 3, 675. [CrossRef]

46. Nagaoka, K.; Fujii, K.; Zhang, H.; Usuda, K.; Watanabe, G.; Ivshina, M.; Richter, J.D. CPEB1 mediates epithelial-to-mesenchyme transition and breast cancer metastasis. Oncogene 2016, 35, 2893-2901. [CrossRef]

47. Garneau, N.L.; Wilusz, J.; Wilusz, C.J. The highways and byways of mRNA decay. Nat. Rev. Mol. Cell Biol. 2007, 8, 113-126. [CrossRef] [PubMed]

48. Chen, C.-Y.A.; Shyu, A.-B. Deadenylation and P-bodies. In Advances in Experimental Medicine and Biology; Springer: Berlin/Heidelberg, Germany, 2013; Volume 768, pp. 183-195. [CrossRef] [PubMed]

49. Perron, G.; Jandaghi, P.; Solanki, S.; Safisamghabadi, M.; Storoz, C.; Karimzadeh, M.; Papadakis, A.I.; Arseneault, M.; Scelo, G.; Banks, R.E.; et al. A General Framework for Interrogation of mRNA Stability Programs Identifies RNA-Binding Proteins that Govern Cancer Transcriptomes. Cell Rep. 2018, 23, 1639-1650. [CrossRef] [PubMed]

50. Truitt, M.L.; Ruggero, D. Erratum: New frontiers in translational control of the cancer genome. Nat. Rev. Cancer 2017, 17, 332. [CrossRef]

51. Hsieh, A.C.; Ruggero, D. Targeting Eukaryotic Translation Initiation Factor 4E (eIF4E) in Cancer. Clin. Cancer Res. 2010, 16, 4914-4920. [CrossRef]

52. Nilsen, T.W.; Graveley, B.R. Expansion of the eukaryotic proteome by alternative splicing. Nature 2010, 463, 457-463. [CrossRef] [PubMed]

53. Biamonti, G.; Catillo, M.; Pignataro, D.; Montecucco, A.; Ghigna, C. The alternative splicing side of cancer. Semin. Cell Dev. Biol. 2014, 32, 30-36. [CrossRef] [PubMed]

54. Dvinge, H.; Kim, E.; Abdel-Wahab, O.; Bradley, R.K. RNA splicing factors as oncoproteins and tumour suppressors. Nat. Rev. Cancer 2016, 16, 413-430. [CrossRef] 
55. Wang, J.; Liu, T.; Wang, M.; Lv, W.; Wang, Y.; Jia, Y.; Zhang, R.; Liu, L. SRSF1-dependent alternative splicing attenuates BIN1 expression in non-small cell lung cancer. J. Cell. Biochem. 2020, 121, 946-953. [CrossRef]

56. Venkat, S.; Tisdale, A.A.; Schwarz, J.R.; Alahmari, A.A.; Maurer, H.C.; Olive, K.P.; Eng, K.H.; Feigin, M.E. Alternative polyadenylation drives oncogenic gene expression in pancreatic ductal adenocarcinoma. Genome Res. 2020, 30, 347-360. [CrossRef]

57. Erson-Bensan, A.E.; Can, T. Alternative Polyadenylation: Another Foe in Cancer. Mol. Cancer Res. 2016, 14, 507-517. [CrossRef] [PubMed]

58. Langa, K.M.; Larson, E.B.; Crimmins, E.M.; Faul, J.D.; Levine, D.A.; Kabeto, M.U.; Weir, D.R. A Comparison of the Prevalence of Dementia in the United States in 2000 and 2012. JAMA Intern. Med. 2017, 177, 51-58. [CrossRef]

59. Nussbacher, J.K.; Tabet, R.; Yeo, G.W.; Lagier-Tourenne, C. Disruption of RNA Metabolism in Neurological Diseases and Emerging Therapeutic Interventions. Neuron 2019, 102, 294-320. [CrossRef] [PubMed]

60. Xue, Y.C.; Ng, C.S.; Xiang, P.; Liu, H.; Zhang, K.; Mohamud, Y.; Luo, H. Dysregulation of RNA-Binding Proteins in Amyotrophic Lateral Sclerosis. Front. Mol. Neurosci. 2020, 13, 78. [CrossRef]

61. Mackenzie, I.R.A.; Rademakers, R.; Neumann, M. TDP-43 and FUS in amyotrophic lateral sclerosis and frontotemporal dementia. Lancet Neurol. 2010, 9, 995-1007. [CrossRef]

62. Abramzon, Y.A.; Fratta, P.; Traynor, B.J.; Chia, R. The Overlapping Genetics of Amyotrophic Lateral Sclerosis and Frontotemporal Dementia. Front. Neurosci. 2020, 14. [CrossRef]

63. Liu, E.Y.; Cali, C.P.; Lee, E.B. RNA metabolism in neurodegenerative disease. Dis. Models Mech. 2017, 10, 509-518. [CrossRef] [PubMed]

64. Johnson, J.O.; Pioro, E.P.; Boehringer, A.; Chia, R.; Feit, H.; Renton, A.E.; Pliner, H.A.; Abramzon, Y.; Marangi, G.; Winborn, B.J.; et al. Mutations in the Matrin 3 gene cause familial amyotrophic lateral sclerosis. Nat. Neurosci. 2014, 17, 664-666. [CrossRef] [PubMed]

65. Wang, J.; Schultz, P.G.; Johnson, K.A. Mechanistic studies of a small-molecule modulator of SMN2 splicing. Proc. Natl. Acad. Sci. USA 2018, 115, E4604-E4612. [CrossRef] [PubMed]

66. Buckanovich, R.J.; Posner, J.B.; Darnell, R.B. Nova, the paraneoplastic Ri antigen, is homologous to an RNA-binding protein and is specifically expressed in the developing motor system. Neuron 1993, 11, 657-672. [CrossRef]

67. Ule, J.; Jensen, K.B.; Ruggiu, M.; Mele, A.; Ule, A.; Darnell, R.B. CLIP identifies Nova-regulated RNA networks in the brain. Science 2003, 302, 1212-1215. [CrossRef] [PubMed]

68. Milne, C.A.; Hodgkin, J. ETR-1, a homologue of a protein linked to myotonic dystrophy, is essential for muscle development in Caenorhabditis elegans. Curr. Biol. 1999, 9, 1243-1246. [CrossRef]

69. Belzil, V.V.; Gendron, T.F.; Petrucelli, L. RNA-mediated toxicity in neurodegenerative disease. Mol. Cell. Neurosci. 2013, 56, 406-419. [CrossRef] [PubMed]

70. Ling, S.C.; Polymenidou, M.; Cleveland, D.W. Converging mechanisms in ALS and FTD: Disrupted RNA and protein homeostasis. Neuron 2013, 79, 416-438. [CrossRef]

71. Kim, H.J.; Kim, N.C.; Wang, Y.D.; Scarborough, E.A.; Moore, J.; Diaz, Z.; MacLea, K.S.; Freibaum, B.; Li, S.; Molliex, A.; et al. Mutations in prion-like domains in hnRNPA2B1 and hnRNPA1 cause multisystem proteinopathy and ALS. Nature 2013, 495, 467-473. [CrossRef]

72. Li, Y.R.; King, O.D.; Shorter, J.; Gitler, A.D. Stress granules as crucibles of ALS pathogenesis. J. Cell Biol. 2013, $201,361-372$. [CrossRef] [PubMed]

73. Courchaine, E.M.; Lu, A.; Neugebauer, K.M. Droplet organelles? EMBO J. 2016, 35, 1603-1612. [CrossRef] [PubMed]

74. Smith, J.; Calidas, D.; Schmidt, H.; Lu, T.; Rasoloson, D.; Seydoux, G. Spatial patterning of P granules by RNA-induced phase separation of the intrinsically-disordered protein MEG-3. Elife 2016, 5, e21337. [CrossRef] [PubMed]

75. Xiang, S.; Kato, M.; Wu, L.C.; Lin, Y.; Ding, M.; Zhang, Y.; Yu, Y.; McKnight, S.L. The LC Domain of hnRNPA2 Adopts Similar Conformations in Hydrogel Polymers, Liquid-like Droplets, and Nuclei. Cell 2015, 163, 829-839. [CrossRef]

76. Vanderweyde, T.; Yu, H.; Varnum, M.; Liu-Yesucevitz, L.; Citro, A.; Ikezu, T.; Duff, K.; Wolozin, B. Contrasting pathology of the stress granule proteins TIA-1 and G3BP in tauopathies. J. Neurosci. 2012, 32, 8270-8283. [CrossRef]

77. Gibbings, D.J.; Ciaudo, C.; Erhardt, M.; Voinnet, O. Multivesicular bodies associate with components of miRNA effector complexes and modulate miRNA activity. Nat. Cell Biol. 2009, 11, 1143-1149. [CrossRef]

78. Wolozin, B.; Apicco, D. RNA binding proteins and the genesis of neurodegenerative diseases. Adv. Exp. Med. Biol. 2015, 822, 11-15. [CrossRef]

79. Yang, C.; Kelaini, S.; Caines, R.; Margariti, A. RBPs Play Important Roles in Vascular Endothelial Dysfunction under Diabetic Conditions. Front. Physiol. 2018, 9, 1310. [CrossRef]

80. Aslam, N.; Zaheer, I. The biosynthesis characteristics of TTP and TNF can be regulated through a posttranscriptional molecular loop. J. Biol. Chem. 2011, 286, 3767-3776. [CrossRef]

81. Zhang, Y.; Si, Y.; Ma, N.; Mei, J. The RNA-binding protein PCBP2 inhibits Ang II-induced hypertrophy of cardiomyocytes though promoting GPR56 mRNA degeneration. Biochem. Biophys. Res. Commun. 2015, 464, 679-684. [CrossRef] [PubMed]

82. Gomes, C.P.C.; Schroen, B.; Kuster, G.M.; Robinson, E.L.; Ford, K.; Squire, I.B.; Heymans, S.; Martelli, F.; Emanueli, C.; Devaux, Y. Regulatory RNAs in Heart Failure. Circulation 2020, 141, 313-328. [CrossRef] [PubMed]

83. Mohibi, S.; Chen, X.; Zhang, J. Cancer the'RBP'eutics-RNA-binding proteins as therapeutic targets for cancer. Pharmacol. Ther. 2019, 203, 107390. [CrossRef] [PubMed] 
84. Stein, C.A.; Castanotto, D. FDA-Approved Oligonucleotide Therapies in 2017. Mol. Ther. 2017, 25, 1069-1075. [CrossRef]

85. Duffy, A.G.; Makarova-Rusher, O.V.; Ulahannan, S.V.; Rahma, O.E.; Fioravanti, S.; Walker, M.; Abdullah, S.; Raffeld, M.; Anderson, V.; Abi-Jaoudeh, N.; et al. Modulation of tumor eIF4E by antisense inhibition: A phase I/II translational clinical trial of ISIS 183750 - An antisense oligonucleotide against eIF4E-In combination with irinotecan in solid tumors and irinotecan-refractory colorectal cancer. Int. J. Cancer 2016, 139, 1648-1657. [CrossRef]

86. Huang, Y.-J.; Xiao, S.; Sun, Z.-L.; Zeng, J.-G.; Liu, Y.-S.; Liu, Z.-Y. Identification of allocryptopine and protopine metabolites in rat liver S9 by high-performance liquid chromatography/quadrupole-time-of-flight mass spectrometry. Rapid Commun. Mass Spectrom. 2016, 30, 1549-1559. [CrossRef] [PubMed]

87. Mongelard, F.; Bouvet, P. AS-1411, a guanosine-rich oligonucleotide aptamer targeting nucleolin for the potential treatment of cancer, including acute myeloid leukemia. Curr. Opin. Mol. 2010, 12, 107-114.

88. Kristensen, L.S.; Hansen, T.B.; Venø, M.T.; Kjems, J. Circular RNAs in cancer: Opportunities and challenges in the field. Oncogene 2018, 37, 555-565. [CrossRef]

89. Abdelmohsen, K.; Panda, A.C.; Munk, R.; Grammatikakis, I.; Dudekula, D.B.; De, S.; Kim, J.; Noh, J.H.; Kim, K.M.; Martindale, J.L.; et al. Identification of HuR target circular RNAs uncovers suppression of PABPN1 translation by CircPABPN1. RNA Biol. 2017, 14, 361-369. [CrossRef]

90. Tian, X.; Gu, T.; Patel, S.; Bode, A.M.; Lee, M.-H.; Dong, Z. CRISPR/Cas9-An evolving biological tool kit for cancer biology and oncology. NPJ Precis. Oncol. 2019, 3, 8. [CrossRef]

91. Gorkovskiy, A.; Reidy, M.; Masison, D.C.; Wickner, R.B. Hsp104 disaggregase at normal levels cures many [PSI $\left.{ }^{+}\right]$prion variants in a process promoted by Sti1p, Hsp90, and Sis1p. Proc. Natl. Acad. Sci. USA 2017, 114, E4193-E4202. [CrossRef]

92. Jackrel, M.E.; DeSantis, M.E.; Martinez, B.A.; Castellano, L.M.; Stewart, R.M.; Caldwell, K.A.; Caldwell, G.A.; Shorter, J. Potentiated Hsp104 variants antagonize diverse proteotoxic misfolding events. Cell 2014, 156, 170-182. [CrossRef]

93. Chen, H.-J.; Mitchell, J.C.; Novoselov, S.; Miller, J.; Nishimura, A.L.; Scotter, E.L.; Vance, C.A.; Cheetham, M.E.; Shaw, C.E. The heat shock response plays an important role in TDP-43 clearance: Evidence for dysfunction in amyotrophic lateral sclerosis. Brain 2016, 139, 1417-1432. [CrossRef] [PubMed]

94. Barmada, S.J.; Serio, A.; Arjun, A.; Bilican, B.; Daub, A.; Ando, D.M.; Tsvetkov, A.; Pleiss, M.; Li, X.; Peisach, D.; et al. Autophagy induction enhances TDP43 turnover and survival in neuronal ALS models. Nat. Chem. Biol. 2014, 10, 677-685. [CrossRef] [PubMed]

95. Wang, I.-F.; Guo, B.-S.; Liu, Y.-C.; Wu, C.-C.; Yang, C.-H.; Tsai, K.-J.; Shen, C.-K.J. Autophagy activators rescue and alleviate pathogenesis of a mouse model with proteinopathies of the TAR DNA-binding protein 43. Proc. Natl. Acad. Sci. USA 2012, 109, 15024-15029. [CrossRef] [PubMed] 